\title{
SHORTEST PATH DETECTION USING CLONAL SELECTION ALGORITHM FOR ERZURUM METROPOLITAN MUNICIPALITY
}

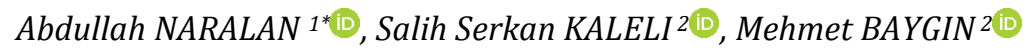 \\ 1Management Information Systems Department, Ataturk University, 25030, Erzurum, Turkey \\ anaralan@atauni.edu.tr \\ 2Department of Business Management and Computer Engineering, Ardahan University, 75000, Ardahan, Turkey \\ salihserkankaleli@ardahan.edu.tr, mehmetbaygin@ardahan.edu.tr
}

Received: 30.10.2017, Accepted: 24.11.2017

*Corresponding author

doi: 10.22531/muglajsci.357621

\section{Abstract}

Optimization algorithms are an approach to solving many problems in everyday life and usually to find the optimal solution for problems with a large solution space. In this study, an optimal route detection approach was developed using the clonal selection algorithm which is a sub-method of the artificial immune system. For this purpose, the road passenger transport network obtained from Erzurum Metropolitan Municipality has been modeled and a bus line which is selected and used from this network has been examined by clonal selection algorithm. The optimization method developed for the proposed approach was implemented in the MATLAB environment and the results obtained are plotted comparatively on Google Maps. The performance of the proposed method was tested and a performance improvement of about 10\% was achieved according to the results obtained.

Keywords: Shortest Path Detection, Clonal Selection Algorithm, Optimization, Traveling Salesman, Artificial Immune System

\section{ERZURUM BÜYÜKŞEHİR BELEDIYYESI İÇİN KLONAL SEÇIM ALGORİTMASI KULLANILARAK EN KISA YOL TESPITI}

Öz

Optimizasyon algoritmaları günlük yaşamdaki birç̧ok problemi çözmeye yarayan ve genellikle büyük bir çözüm uzayına sahip problemlerde optimal çözümü tespit etmeye yarayan yaklaşımlar bütünüdür. Bu çalışmada yapay bağışıklık sisteminin alt yöntemi olan klonal seçim algoritması kullanılarak bir optimum rota tespit yaklașımı geliștirilmiștir. Bu amaçla Erzurum Büyükşehir Belediyesinden temin edilen karayolu yolcu taşıma ağı modellenmiş olup, bu ağdan seçilen ve hali hazırda kullanılan bir otobüs hattı klonal seçim algoritması ile incelenmiștir. Önerilen yaklașım için geliștirilen optimizasyon yöntemi MATLAB ortamında gerçekleştirilmiş ve elde edilen sonuçlar Google Maps üzerinde karşılaştırmalı olarak çizdirilmiştir. Önerilen yöntemin performansı test edilmiş ve elde edilen sonuçlara göre yaklaşı \%10'luk bir performans artışı sağlanmıştır.

Anahtar Kelimeler: En Kısa Yol Tespiti, Klonal Seçim Algoritması, Optimizasyon, Gezgin-Satıcı, Yapay Bağışıklık Sistem

\section{Introduction}

The shortest path problem is a kind of combinatorial problem which is quite common in the world [1]. In this type of problem, it is aimed to determine the optimal path on condition that each node is visited once from a certain number of nodes. The shortest path problem is also referred to as the traveling salesman problem in the literature. In the traveling salesman problem, the basic logic involves selling a merchant's merchandise by visiting each city one time and eventually returning to the starting point [2]. The basic principle in this problem is to carry out all these operations by following the shortest route [3]. This problem, which is quite common in the literature, is called NP complete problem and the solution space for this problem is quite wide. Furthermore, it is almost impossible to find a solution for the traveling salesman problem in polynomial time space [4]. At this point, optimization-based methods are often introduced and the optimal route can be determined from such large solution spaces.

One of the studies related to this subject in this framework, [5] have tried to solve the symmetric and asymmetric traveling salesman problem. For this purpose, a separate bat algorithm, a new optimization approach, has been developed. The proposed approach has been tested with 35 different traveling salesman problem examples and compared with 5 different optimization techniques. In addition, contributions to improve the classical bat algorithm are presented in the study. When the results obtained in the study are examined, it is observed that the proposed approach gives better results than the other 5 methods. In another study on the traveling salesman problem, a hybrid approach based on particle swarm algorithm, ant colony algorithm and 3-0pt algorithm is proposed. In this study, a particle swarm algorithm is used to optimize the parameters affecting the performance of the ant colony algorithm. Furthermore, it is aimed to develop local solutions by using 3-Opt heuristic method which is another method used in the study. Experimental studies conducted during the study showed that the proposed approach yielded better results than many studies in the literature in terms of the quality and accuracy of the solution [6]. A block diagram summarizing this work in the literature is as shown in Fig. 1. 


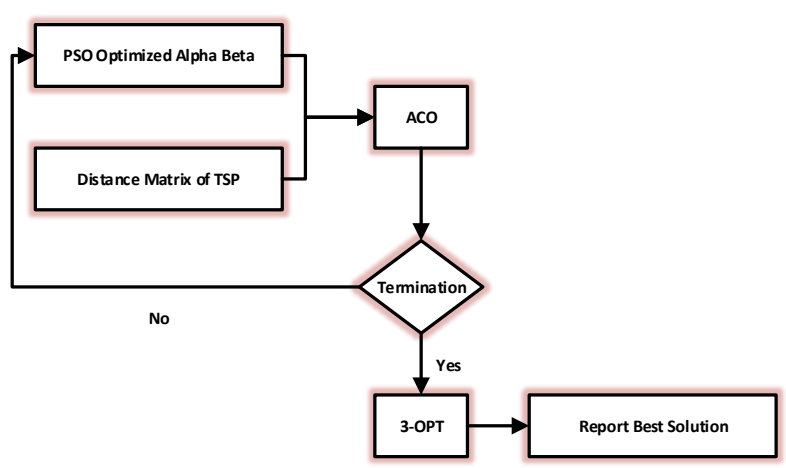

Figure 1. An example approach from literature [6].

The traveling salesman problem is one of the most important problems encountered in the literature and trying to solve. In this study, genetic algorithms and ant colony algorithm are used together and a solution to the traveler salesman problem is produced. The proposed approach is based on the analysis of cities in Turkey. Ant colony algorithm gave better results than genetic algorithm in terms of both route distance and route calculation time [7]. In another work on the subject, Groba et al. [8] combined a predictive technique for solving the dynamic traveling salesman problem and a genetic algorithm. In this study, route optimization has been done for a scenario where the targets are constantly moving. For this purpose, a genetic algorithm has been developed that feeds Newton's equation of motion. The results obtained in the study proved that the trajectory prediction based genetic algorithm approach gives better and more effective results than the methods used frequently in the literature. Patients on a waiting list for kidney transplantation have been optimized in a study inspired by the traveler salesman problem. It has been observed that the proposed method gives effective results [9]. In another study on the subject, it has been presented that the service times related to time are solved by using the traveler salesman problem. In the problem, it is aimed to reduce the total duration of the total route, including total road time and total service time [10]. In another study, ant colony optimization algorithm was tried to solve dynamic optimization problem of immigrant plans. To this end, two new types of dynamic traveler salesman problem are proposed in the study. It has been observed that the proposed method gives better results than other ant colony algorithms in the literature [11]. In another study, optimization of road transport was achieved using genetic algorithms. With the proposed method, optimization was performed according to the data from Google Maps and about 5\% performance was achieved [12].

Optimization techniques are frequently used in the literature in many different areas. In this framework, optimal portfolio selection was performed using genetic algorithms. This approach, which takes stock market data as input, enables the system to select the most appropriate portfolio according to the yield and risk rates determined by the user [13]. Baygin et al. [14] modeled group elevator systems in a study they carried out and tried to optimize the operation of the system with 3 different optimization techniques. Genetic algorithms, DNA computation algorithms and clonal selection algorithms have been used in the study and an additional method has been developed in addition to optimization methods with the estimation approach suggested in the study. All the results obtained from the methods used in this study are given as input parameters to the fuzzy system and it is possible to select the most appropriate one from the results obtained from 4 different methods. A block diagram summarizing this approach suggested in the study is as shown in Fig. 2.

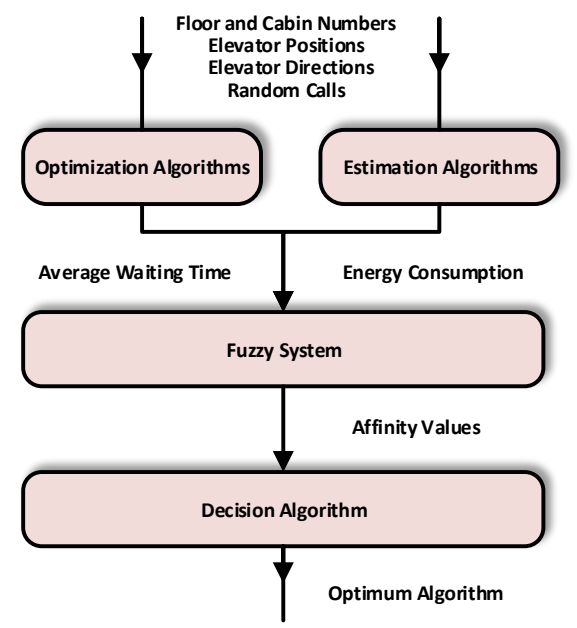

Figure 2. An example optimization approach [14].

In this study, a route for the passenger transport network provided by the Erzurum Metropolitan Municipality and actively used has been modeled and optimized. For this purpose clonal selection approach which is one of the artificial immune system algorithms has been used in the study and the route has been optimized. In addition, the simulations performed and the route before and after the optimization process were examined and the performance of the proposed approach was verified. The approach proposed in this framework is presented in the second section. In the third part of the study, simulation results are given. In the fourth and last section, the results and the details of future works are included.

\section{Proposed Method}

In this study, it is tried to solve the traveling salesman problem which is a common problem in the literature by using clonal selection algorithm. For this purpose, road passenger transport routes obtained from Erzurum Metropolitan Municipality have been examined and optimized. The approach suggested in the study was to shorten the routes used by the buses and accordingly to reduce the average travel time of the passengers.

As stated at the beginning of the chapter, the aim of the study is to solve the problem of the traveler based on the approach suggested. The traveling salesman problem can usually be examined in two subsections [15]. These are the symmetric and asymmetric traveling salesman problem respectively. In the symmetric traveling salesman problem, the cost of the paths between the two nodes is the same. In other words, the cost of transportation from point A to point $B$ and the cost of transportation from point $B$ to point $A$ are the same. In the case of the asymmetric traveling salesman problem, the costs of transportation can be different from each other. Usually the problem is asymmetrical in the solutions made by going out of the way of real data. The main reason for this is that some of the routes in traffic are one way. In this work, which is carried out when it is thought in this frame, the problem can be expressed as asymmetric traveling salesman problem. An exemplary scheme that summarizes the symmetric and asymmetric states of the traveling salesman problem, which is basically composed of two parts is given in Fig. 3 [16]. 


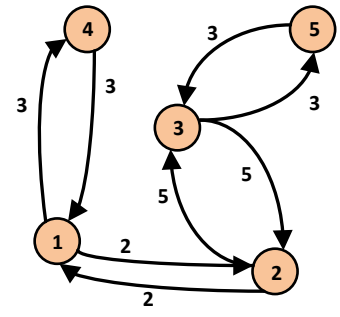

(a)

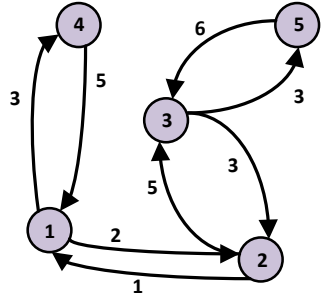

(b)
Figure 3. a) Symmetric and b) asymmetric traveling salesman problem

Artificial immune systems are those approaches that exemplify and work on the immune system of the human body [17]. These systems are generally divided into two. These are negative selection and clonal selection algorithms, respectively. Negative selection algorithm is generally used to detect and capture unwanted situations such as viruses. The clonal selection algorithm aims to find an optimal solution from a large solution space similar to genetic algorithms [18]. In this study, clonal selection algorithm was used for artificial immune systems.

As mentioned at the beginning of this chapter, this optimization approach is a system inspired by the working principle of the human body. When a foreign substance enters the human body from outside (antigen), the immune system produces an antibody against this antigen. The antibody produced will recognize the antigen after a certain period of time and become able to fight it. After this point, the antibody will constantly divide and destroy the antigens entering the body. The clonal selection algorithm works just as it is in the antigen-antibody relationship and can detect the optimal result [19]. The steps of the clonal selection algorithm from the artificial immune system are presented as follows. In addition, a flow diagram summarizing the operation of this method appears as given in Fig. 4 [14].

1. The antibodies compromising body antibody repertoire constitute the initial solution set.

2. Degree of similarity of antibodies is calculated.

3. n pieces of highest similar antibody is selected.

4. Proportional to the degree of similarity of the $n$ pieces of the selected antibody, the high degree of similarity cloning of antibody is carried out.

5. Antibodies with a high degree of similarity are exposed to the mutation as a manner to become less.

6. The degrees of similarity of mutated clones are determined.

7. $n$ pieces of highest similar antibody is selected again.

8. Change of $d$ pieces of antibodies in lowest degree of similarity with newly produced antibodies is realized.

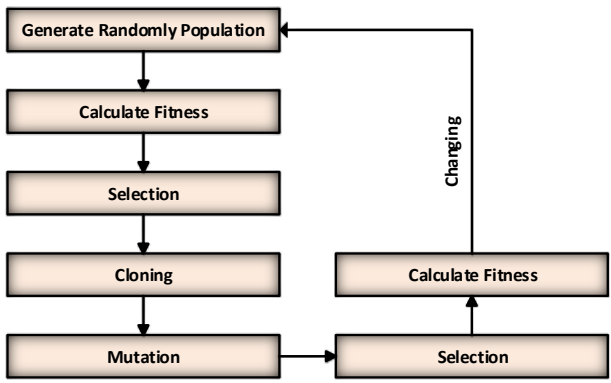

Figure 4. Clonal Selection Algorithm [14]
- Random Initially Population Create: The first step of the clonal selection algorithm is random population generation. A total of 25 bus stops are located in this study. Because of the ease of use within the application, permutation coding is preferred as the coding method. In addition, a total population of 100 elements was used in the study.

- Calculate Fitness: The next step of the algorithm is to determine the objective function and the individuals randomly generated in the previous step are subjected to this function. The objective function used in the application is given in Eq. 1 .

$$
\begin{gathered}
\operatorname{Goal}(i)=\sum \operatorname{Cost}[\text { start }, \text { next }] \\
\text { start }=\text { next }
\end{gathered}
$$

- Selection: At this stage of the clonal selection algorithm, firstly the individuals with the best fitness value are determined. Then the best $n$ individual is selected according to the fitness measure $\left(P_{n}\right)$.

- $\quad$ Cloning: The best $\mathrm{n}$ individuals selected in the population are reproduced. In other words, these individuals are copied and a temporary population is brought to the scene. The size of the transient population has parallel cloning process suitability value. In addition, the number of clones in the study is determined according to Eq. 2.

$$
N_{c}=\sum_{i=1}^{n} \text { round }\left(\frac{\beta * N}{i}\right)
$$

where $b$ is multiplier factor, $N$ is the number of individuals to be used for the clone and round represents the rounding function.

- Mutation: The clones produced are subjected to mutation treatment. The purpose of this operation is to increase the diversity of the clones and in possible new solution may be obtained.

- Termination: The termination criterion is the section that determines how long the clonal selection algorithm will work. This section may be for any period or it may be the number of iterations that are determined more over time. In this study, the iteration step is determined and the algorithm is replicated 1000 times.

\section{Simulation Results}

In this study, optimal route detection was performed using artificial immune system clonal selection algorithm. The data used in the study are obtained from the Erzurum Metropolitan Municipality road transport unit and are used in real time. A total of 25 stations are located on the route, and the transportation route is optimized by using the clonal selection algorithm. When the application is developed, only a certain part of the distance table used is shown in Table 1.

As noted at the beginning of the chapter, only a specific section is presented in Table 1 due to the multiplicity of data. But it is located in total of 25 stops on the route. Detailed coordinate information of these stations are given in Table 2. 
Table 1. Distance between stops

\begin{tabular}{c|cccccccccccccc} 
& 1 & 2 & 3 & 4 & 5 & 6 & 7 & 8 & 9 & 10 & 11 & 12 & 13 & 14 \\
\hline 1 & 0 & 0.45 & 0.8 & 0.75 & 0.95 & 1.9 & 3.3 & 3.6 & 4.0 & 4.3 & 5.1 & 5.5 & 5.8 & 5.9 \\
2 & 0.4 & 0 & 0.35 & 0.6 & 0.90 & 2.0 & 3.6 & 4.0 & 4.4 & 4.7 & 5.2 & 5.8 & 6.1 & 6.3 \\
3 & 0.75 & 0.35 & 0 & 0.50 & 0.90 & 2.0 & 3.6 & 4.1 & 4.8 & 5.1 & 5.2 & 5.8 & 6.1 & 6.6 \\
4 & 0.7 & 0.60 & 0.50 & 0 & 0.35 & 1.5 & 3.0 & 3.5 & 4.0 & 4.3 & 4.6 & 5.2 & 5.5 & 6.0 \\
5 & 0.9 & 0.90 & 0.9 & 0.35 & 0 & 1.1 & 2.5 & 3.0 & 3.5 & 3.8 & 4.2 & 4.8 & 5.1 & 5.8 \\
6 & 1.9 & 2.3 & 2.1 & 1.5 & 1.2 & 0 & 1.4 & 1.9 & 2.4 & 2.7 & 3.1 & 3.7 & 4.0 & 4.3 \\
7 & 3.7 & 4.1 & 4.4 & 3.9 & 2.8 & 2.0 & 0 & 0.5 & 1.0 & 1.3 & 1.8 & 2.4 & 2.7 & 2.8 \\
8 & 3.8 & 4.2 & 4.6 & 4.1 & 3.7 & 2.7 & 1.0 & 0 & 0.5 & 0.75 & 1.3 & 1.9 & 2.2 & 2.5 \\
9 & 4.7 & 5.1 & 5.2 & 4.6 & 4.2 & 3.2 & 1.9 & 1.5 & 0 & 0.29 & 0.85 & 1.4 & 1.7 & 2.2 \\
10 & 4.7 & 4.9 & 4.9 & 4.3 & 3.9 & 2.9 & 1.9 & 1.3 & 0.80 & 0 & 0.55 & 1.1 & 1.4 & 1.9 \\
11 & 5.0 & 5.4 & 5.4 & 4.8 & 4.5 & 3.4 & 2.2 & 1.9 & 1.4 & 1.3 & 0 & 1.0 & 1.3 & 1.8 \\
12 & 5.8 & 6.2 & 6.4 & 5.9 & 5.6 & 4.7 & 3.0 & 2.7 & 2.1 & 2.0 & 1.6 & 0 & 0.3 & 0.8 \\
13 & 5.5 & 5.9 & 6.1 & 5.5 & 5.0 & 4.1 & 2.7 & 2.4 & 1.8 & 1.7 & 1.6 & 1.1 & 0 & 0.5 \\
14 & 6.0 & 6.5 & 6.6 & 6.0 & 5.5 & 4.8 & 3.2 & 2.9 & 2.3 & 2.2 & 2.0 & 1.2 & 0.8 & 0 \\
\hline
\end{tabular}

Table 2. Detailed coordinate information of stops

\begin{tabular}{|c|c|c|c|}
\hline Stop No. & Coordinate & Stop No. & Coordinate \\
\hline 1 & $39^{\circ} 52^{\prime} 15.93 " \mathrm{~N}, 41^{\circ} 14^{\prime} 57.31^{\prime \prime E}$ & 14 & $39^{\circ} 54^{\prime} 47.33^{\prime \prime N}, 41^{\circ} 16^{\prime} 14.85^{\prime \prime E}$ \\
\hline 2 & $39^{\circ} 52^{\prime} 20.98^{\prime \prime N}, 41^{\circ} 14^{\prime} 47.38^{\prime \prime E}$ & 15 & $39^{\circ} 54^{\prime} 27.30^{\prime \prime} \mathrm{N}, 41^{\circ} 16^{\prime} 43.94^{\prime \prime E}$ \\
\hline 3 & $39^{\circ} 52^{\prime} 24.38^{\prime \prime N}, 41^{\circ} 14^{\prime} 37.34^{\prime \prime E}$ & 16 & $39^{\circ} 54^{\prime} 43.03^{\prime \prime} \mathrm{N}, 41^{\circ} 16^{\prime} 21.68^{\prime \prime} \mathrm{E}$ \\
\hline 4 & $39^{\circ} 52^{\prime} 35.07^{\prime \prime N}, 41^{\circ} 14^{\prime} 45.09^{\prime \prime} \mathrm{E}$ & 17 & $39^{\circ} 54^{\prime} 43.37^{\prime \prime N}, 41^{\circ} 15^{\prime} 57.44^{\prime \prime E}$ \\
\hline 5 & $39^{\circ} 52^{\prime} 40.61^{\prime \prime N}, 41^{\circ} 14^{\prime} 59.00^{\prime \prime E}$ & 18 & $39^{\circ} 54^{\prime} 30.78^{\prime \prime N}, 41^{\circ} 15^{\prime} 55.20^{\prime \prime E}$ \\
\hline 6 & $39^{\circ} 53^{\prime} 0.43^{\prime \prime} \mathrm{N}, 41^{\circ} 15^{\prime} 23.61^{\prime \prime} \mathrm{E}$ & 19 & $39^{\circ} 53^{\prime} 59.77^{\prime \prime N}, 41^{\circ} 16^{\prime} 0.27^{\prime \prime}$ \\
\hline 7 & $39^{\circ} 53^{\prime} 34.11^{\prime \prime N}, 41^{\circ} 16^{\prime} 4.11^{\prime E}$ & 20 & $39^{\circ} 53^{\prime} 53.37^{\prime \prime N}, 41^{\circ} 16^{\prime} 13.54^{\prime \prime E}$ \\
\hline 8 & $39^{\circ} 53^{\prime} 42.69^{\prime \prime} \mathrm{N}, 41^{\circ} 16^{\prime} 19.70^{\prime \prime} \mathrm{E}$ & 21 & $39^{\circ} 53^{\prime} 45.02^{\prime \prime N}, 41^{\circ} 16^{\prime} 18.42^{\prime \prime} \mathrm{E}$ \\
\hline 9 & $39^{\circ} 53^{\prime} 55.45^{\prime \prime} \mathrm{N}, 41^{\circ} 16^{\prime} 12.58^{\prime \prime} \mathrm{E}$ & 22 & $39^{\circ} 53^{\prime} 34.83^{\prime \prime N}, 41^{\circ} 16^{\prime} 3.25^{\prime \prime E}$ \\
\hline 10 & $39^{\circ} 54^{\prime} 0.28^{\prime \prime N}, 41^{\circ} 16^{\prime} 2.13^{\prime \prime E}$ & 23 & $39^{\circ} 53^{\prime} 13.85^{\prime \prime N}, 41^{\circ} 15^{\prime} 43.11^{\prime E}$ \\
\hline 11 & $39^{\circ} 54^{\prime} 11.18 " \mathrm{~N}, 41^{\circ} 15^{\prime} 46.34^{\prime \prime} \mathrm{E}$ & 24 & $39^{\circ} 52^{\prime} 38.29^{\prime \prime} \mathrm{N}, 41^{\circ} 14^{\prime} 52.92^{\prime \prime E}$ \\
\hline 12 & $39^{\circ} 54^{\prime} 33.63^{\prime \prime N}, 41^{\circ} 15^{\prime} 55.34^{\prime \prime E}$ & 25 & $39^{\circ} 52^{\prime} 22.28^{\prime \prime N}, 41^{\circ} 14^{\prime} 53.55^{\prime E}$ \\
\hline 13 & $39^{\circ} 54^{\prime} 42.46^{\prime \prime} \mathrm{N}, 41^{\circ} 15^{\prime} 56.61^{\prime \prime} \mathrm{E}$ & & \\
\hline
\end{tabular}

As can be seen from Table 2, the coordinates of the routes used in the study are given. The values in Table 1 used in the application are calculated and obtained according to these coordinate values. 1 stop represents the start coordinates of the bus stop, 25 stops represent the finish coordinates of the bus stop. Also, if these coordinates are checked on Google
Maps, it will be seen that stops 1 and 25 are very close together. This is because the bus is going back to where it started again. An image of this optimization process performed using the clonal selection algorithm from the artificial immune system is presented in Fig. 5.

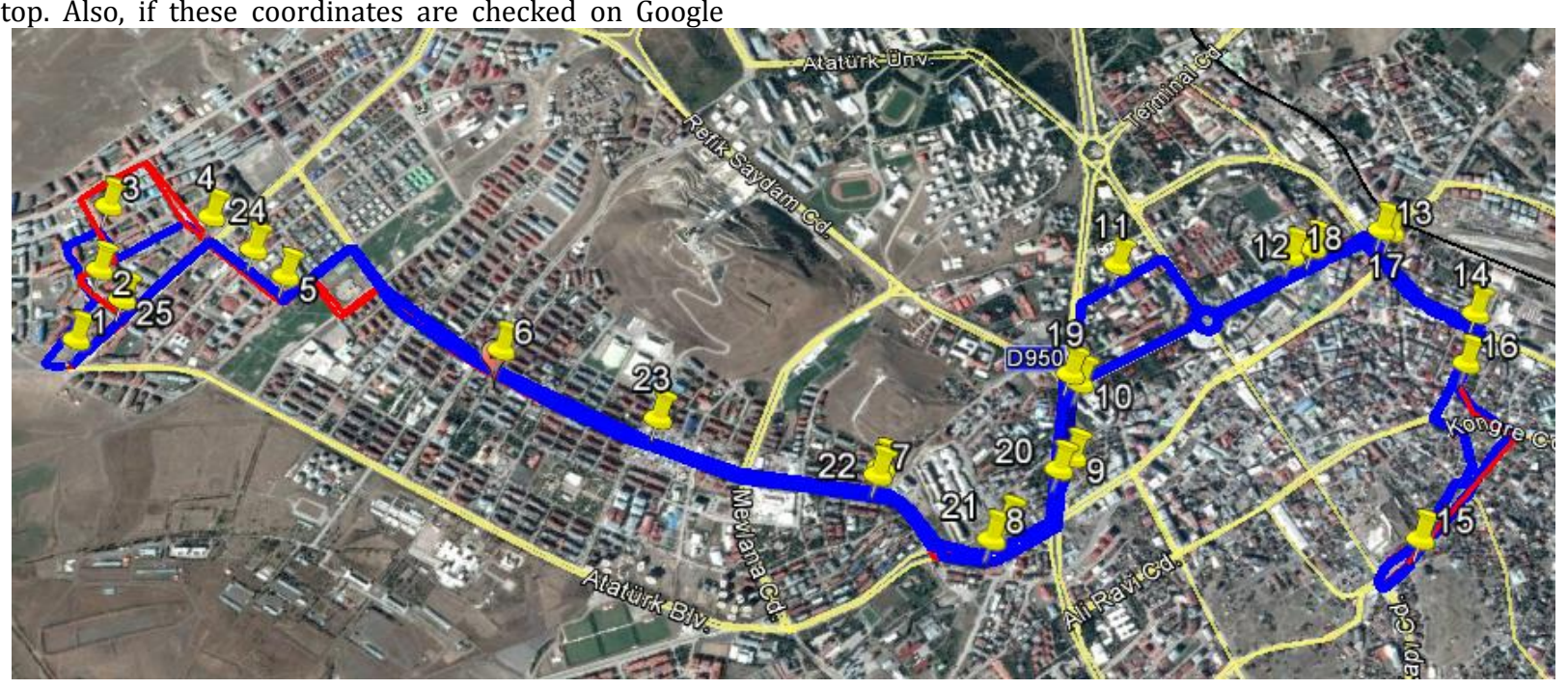

Figure 5. Simulation results on Google Maps 
As can be seen from Fig. 5, there are two different colors on the route, red and blue. The red color of these colors indicates the route before the optimization process, while the blue color shows the results of the route obtained after the optimization process. The results obtained according to the simulation studies carried out during the application are presented in Table 3. In addition, a comparative result with an example study from the literature is given in Table 4.

Table 3. Simulation Results

\begin{tabular}{cc}
\hline Features & Values \\
\hline Total Stops & 25 \\
Initial Route & $17.35 \mathrm{~km}$ \\
Final Route & $15.65 \mathrm{~km}$ \\
Difference & $1.7003 \mathrm{~km}$ \\
Percentage & $\% 0.098$ \\
\hline
\end{tabular}

Table 4. Comparison with Literature

\begin{tabular}{ccccc}
\hline Method & $\begin{array}{c}\text { Total } \\
\text { Stop }\end{array}$ & $\begin{array}{c}\text { Navigation } \\
\text { Stops }\end{array}$ & $\begin{array}{c}\text { Method } \\
\text { Perf. (\%) }\end{array}$ & Paper \\
\hline $\begin{array}{c}\text { Genetic } \\
\text { Algorithm } \\
\text { Clonal }\end{array}$ & 17 & Random & $\sim \% 5$ & {$[12]$} \\
$\begin{array}{c}\text { Selection } \\
\text { Algorithm }\end{array}$ & 25 & In Order & $\sim \% 10$ & $\begin{array}{c}\text { This } \\
\text { Paper }\end{array}$ \\
\hline
\end{tabular}

\section{Conclusion}

In this study, shortest path detection was performed by using clonal selection algorithm from artificial immune system. For this purpose, bus routes which were actively used by the Directorate of Transportation of Erzurum Metropolitan Municipality were provided and tried to be optimized. Approximately $10 \%$ performance was achieved with the proposed approach and a new route was determined taking into account the positions of the stops. In addition, the result obtained in the application is marked on Google Maps, and the results are visualized.

Approximately $1.7 \mathrm{~km}$ of performance improvement has been achieved on the existing route with this proposed approach and this performance increase will be observed every time during the day. In this respect, passenger transport buses have been reduced in fuel consumption and maintenance costs as well as in the average passenger travel time

\section{Acknowledgment}

We thank to Erzurum Metropolitan Municipality and Public Transport Directorate for provided data in this study. This article was presented as an oral presentation at the IMISC2017.

\section{References}

[1] Abeysundara, S., Giritharan, B., and Kodithuwakku, S., "A Genetic algorithm approach to solve the shortest path problem for road maps", In Proceedings of the International Conference on Information and Automation, pp. 272-275, 2005.

[2] Barketau, M., and Pesch, E., "An approximation algorithm for a special case of the asymmetric travelling salesman problem", International Journal of Production Research, vol. 54, no. 14, pp. 4205-4212, 2016.

[3] Dorigo, M., and Gambardella, L. M., "Ant-Q: A reinforcement learning approach to the traveling salesman problem", In Proceedings of ML-95, Twelfth Intern. Conf. on Machine Learning, pp. 252-260, 2016.

[4] Bartal, Y., Gottlieb, L. A., and Krauthgamer, R., "The traveling salesman problem: low-dimensionality implies a polynomial time approximation scheme", SIAM Journal on Computing, vol. 45, no. 4, pp. 1563-1581, 2016.

[5] Osaba, E., Yang, X. S., Diaz, F., Lopez-Garcia, P., and Carballedo, R., "An improved discrete bat algorithm for symmetric and asymmetric Traveling Salesman Problems", Engineering Applications of Artificial Intelligence, vol. 48, pp. 59-71, 2016.

[6] Mahi, M., Baykan, Ö. K., and Kodaz, H., "A new hybrid method based on particle swarm optimization, ant colony optimization and 3-opt algorithms for traveling salesman problem", Applied Soft Computing, vol. 30, pp. 484-490, 2015.

[7] Dikmen, H., Dikmen, H., Elbir, A., Eksi Z., and Çelik, F., "Gezgin satıcı probleminin karınca kolonisi ve genetik algoritmalarla eniyilemesi ve karșılaştırılması", Süleyman Demirel Üniversitesi Fen Bilimleri Enstitüsü Dergisi, vol. 18, no. 1, pp. 8-13, 2014.

[8] Groba, C., Sartal, A., and Vázquez, X. H., "Solving the dynamic traveling salesman problem using a genetic algorithm with trajectory prediction: An application to fish aggregating devices", Computers \& Operations Research, vol. 56, pp. 22-32, 2015.

[9] Anderson, R., Ashlagi, I., Gamarnik, D., and Roth, A. E., "Finding long chains in kidney exchange using the traveling salesman problem", Proceedings of the National Academy of Sciences, vol. 112, no. 3, pp. 663-668, 2015.

[10] Taş, D., Gendreau, M., Jabali, O., and Laporte, G., "The traveling salesman problem with time-dependent service times", European Journal of Operational Research, vol. 248, no. 2, pp. 372-383, 2016.

[11] Mavrovouniotis, M., and Yang, S., "Ant colony optimization with immigrants schemes for the dynamic travelling salesman problem with traffic factors", Applied Soft Computing, vol. 13, no. 10, pp. 4023-4037, 2013.

[12] Baygin, M., Kaleli, S. S., and Naralan A., Optimal Route Detect Based On Genetic Algorithm for Erzurum Metropolitan Municipality" 5th International Conference on Advanced Technology \& Sciences (ICAT'17), pp. 167171, 2017.

[13] Zeren, F., and Baygin, M., "Genetik Algoritmalar ile Optimal Portföy Seçimi: BİST-30 Örneği”, Journal of Business Research Turk, vol. 7, no. 1, pp. 309-324, 2015.

[14] Baygin, M., and Karakose, M., "A new intelligent group elevator control approach", 15th International Symposium in Mechatronika, pp. 1-6, 2012.

[15] Rego, C., Gamboa, D., and Glover, F., "Doubly-rooted stem-and-cycle ejection chain algorithm for the asymmetric traveling salesman problem", Networks, vol. 68, no. 1, pp. 23-33, 2016.

[16] Subramanyam, A., and Gounaris, C. E., "A branch-and-cut framework for the consistent traveling salesman problem", European Journal of Operational Research, vol. 248, no. 2, pp. 384-395, 2016.

[17] Aydin, I., Karakose, M., and Akin, E., "A multi-objective artificial immune algorithm for parameter optimization in support vector machine", Applied Soft Computing, vol. 11, no. 1, pp. 120-129, 2011.

[18] Zhang, W., Lin, J., Jing, H., and Zhang, Q., “A Novel Hybrid Clonal Selection Algorithm with Combinatorial Recombination and Modified Hypermutation Operators for Global Optimization", Computational Intelligence and Neuroscience, vol. 2016, 2016.

[19] Díaz-Cortés, M. A., Cuevas, E., and Rojas, R., "Clonal Selection Algorithm Applied to Circle Detection", In Engineering Applications of Soft Computing, vol. 129, pp. 143-164, 2017. 